\title{
TELAAH FENOMENOLOGI ATAS MIKRAJ RUHANI SUNAN GUNUNG DJATI
}

\author{
Dodo Widarda \\ UIN Sunan Gunung Djati Bandung \\ E-mail: dodowidarda@gmail.com
}

\begin{abstract}
ABSTRAK
Positivisme sebagai basis pandangan dunia memiliki kecenderungan reduksionistik ketika berbicara realitas. Karena telah mengakibatkan dehumanisasi, telah menuai kritik secara filosofis. Kritik tersebut salah satunya berasal dari fenomeologi, sebuah disiplin ilmu yang dikembangkan untuk mengatasi keterbatasan, termasuk untuk berbicara karamah wali. Tulisan ini bertitik dari pertanyaaan, 1. Bagaimanakah pendekatan fenomenologi ketika berbicara karamah wali? 2. Bagaimanakah pendekatan fenomeologi atas peristiwa mikraj ruhani Sunan Gunung Djati? Dari dua pertanyaan tersebut penulis mendapatkan jawaban. 1. Hal-hal khawariqul 'adah (sesuatu yang keluar dari kelajiman) bisa didekati melalui fenomenologi. Melalui prinsip back to the thing themselves (kembali sesuatu pada hakikatnya sendiri), karamah para wali, yang tertolak lewat positivisme serta saintisme, merupakan fakta mental yang benar-benar terjadi. 2. Mikraj ruhani Sunan Gunung Djati yang bertemu Rasulullah, dengan pendekatan fenomenologi, bukanlah sesuatu yang tertolak kemungkinannya. Pengalaman ruhani tersebut adalah bagian integral dari hagiografi spiritual seperti juga para wali sufi yang lain: Syaikh Abdul Qodir Al-Jailani, ‘Abd Al-Aziz Al-Dabbagh, Syaikh Ahmad Tijani, dan lain-lain.
\end{abstract}

KATA KUNCI

Mi'raj;Fenomenologi; Sunan Gunung Djati; Spiritual

DOI: https://doi.org/10.15575/saq.v2i1.2391

\section{A. PENDAHULUAN}

Positivisme sebagai sebagai basis pandangan dunia masyarakat modern memiliki kecenderungan sangat reduksionistik ketika berbicara realitas. Realitas hanya dipahami sebatas aspek faktual atau nyata saja, serta dijadikan sebagai satu-satunya ukuran kebenaran. Di luar masalah yang dahir, tidak ada realiatas apapun yang bisa diterima sebagai kebenaran. Karakteristik progres serta linear dari pemikiran Comte, telah menempatkan fase positivistik sebagai puncak perkembangan masyarakat. Urutan dari fase-fase tersebut adalah teologis, filosofis serta positivis. Fase terakhir adalah ketika terjadi kejayaan sains dan teknologi serta sudut pandang manusia sangat didominasi saintisme.

Positivisme yang bertugas untuk mengkoordinasi ilmu-ilmu lain serta diyakini bisa membuat desain ilmu pengetahuan dengan fundamen yang kuat dan terpercaya, menyandarkan pada observasi, eksperimen, serta komparasi berbagai ilmu, terutama pada bidang eksak. (Lubis, 2002/2003:5) Watak yang reduksionistik dari ilmu ini dan kemampuannya untuk melihat realitas berdasar kenyataan-kenyataan fisik semata, telah benyak menuai kritik dari para ilmuwan Barat sendiri. Salah satunya adalah kritik melalui 
pendekatan fenomeologi yang berusaha untuk menorobos kenyataan, tidak sebatas pada aspek yang fisik semata, tapi pada hakikat dari sesuatu itu sendiri, menjangkau hal-hal yang kenyataannya tidak bisa dijamah dengan pendekatan positivistik semata.

Tulisan ini bermaksud untuk mengungkap pendekatan fenomenologi atas peristiwa mikraj ruhani Sunan Gunung Djati yang dalam salah satu pengalaman spiritualnya bertemu dengan Rasulullah Saw. Dalam tulisan Dadan Wildan, peristiwa "bertemunya" Sunan Gunung Djati dengan Nabi itu sangat mustahil terjadi, serta dianggap unsur peniruan saja. Bahkan pertemuan dengan nabi-nabi lain seperti Nabi Khidir, Nabi Sulaeman, Nabi Ilyas merupakan sesuatu yang tidak bisa diterima secara akal, apalagi nabi yang disebutkan itu masa hidupnya, sangat jauh dari masa Rasululullah. Jadi menurut Dadan Wildan, kisah itu merupakan kreativitas pengarang semata.(Wildan, 2012: 178) Melalui pendekatan fenomenologi serta cara pandang sufisme, penulis bermasud mengungkapkan masalah mikraj ruhani sebagai peristiwa yang tidak hanya disandarkan pada kreativitas pengarang semata. Tetapi sebagai sesuatu yang benar-benar terjadi pada peristiwa mikraj ruhani Sunan Gunung Djati.

\section{B. PENDEKATAN FENOMENOLOGI TERHADAP KARAMAH WALI}

Pendekatan positivisme berbicara realitas hanya dari satu dimensi saja yang bersifat fisik, dan tidak akan mampu menjangkau fakta yang terjadi di luar nalar biasa, seperti mukjizat para nabi serta seperti apa yang dituliskan Ernst tentang karamah para wali. Sebagaimana yang ditunjukan oleh hagiografi-hagiografi kehidupan mereka, kedekatan wali terhadap Allah ditampakkan dengan kekuatan yang luar biasa (barakah) yang ditunjukkan dengan penampakan keajaiban luar biasa (karamah). Kekuatan tersebut bisa berupa kemampuankemampuan yang luar biasa seperti membaca pikiran, menyembuhkan orang sakit, menghidupkan orang mati, mengendalikan benda dan binatang, terbang, berjalan di atas air, berubah bentuk dan berada di dua tempat pada suatu waktu (bilocation). (Ernst, 2003:85)

Walaupun karamah para wali ini bukan tujuan, serta efek saja dari istiqamahnya amalan, Ernst sendiri menulis dengan mengutip Al-Qusyairi, bahwa seorang wali tidaklah perlu untuk menampakkan karamah, walaupun mungkin mudah untuk menampakkannya. Para nabi diutus Allah pada kaumnya masingmasing, dan keajaiaban yang dimiliki oleh para nabi (mukjizat) memang diperlukan untuk menegakkan ajaran yang dibawanya. Namun berbeda dengan misi publik para nabi, status para wali bersifat rahasia, tidak penting apakah ada yang tahu bahwa seseorang adalah wali atau bukan, sehingga keajaiban tidak penting bagi mereka.(Ernst, 2003:85) Kalau karamat para wali itu kemudian ke publik, bukanlah sesuatu yang dideklarasikan oleh wali bersangkutan, melainkan Allah saja yang menghendaki hal itu bisa terjadi.

Rejim positivisme Comte, pasti akan menolak bentuk-bentuk khawariqul 'adah (bentuk-bentu yang keluar dari kelajiman) seperti ini. Terlebih seperti apa yang dituliskan Ernst, kalangan intelektual Eropa sejak abad pencerahan tidak lagi mempercayai adanya keajaiban seperti ini. Para kritikus seperti David Hume mengungkapkan argumenargumen yang seakan tidak terbantahkan bahwa karamah itu bukan apa-apa, melainkan takhayul atau bohongan meskipun ada juga bantahan dari para pembela karamah seperti C.S. Lewis. Adopsi otoritas secara ilmiah masuk juga ke ranah humaniora. Tak pelak lagi, keberhasilan pragmatik metode ilmiah telah diterjemahkan ke dalam sebuah ideologi baru tentang otoritas, yakni suatu paham ilmu pengetahuan (scientism) yang bisa jadi sama tak bertoleransinya terhadap ortodoksi religius yang digantikannya. Demikian sehingga banyak sarjana yang mengkaji agama, kemudian merasa perlu untuk meningalkan cerita-cerita tentang keajaiban dengan anggapan bahwa itu adalah suatu cerita yang diperuntukan bagi orang awam. Padahal esensinya karamah dialami sebagai intervensi kekuatan Ilahiyah dalam kehidupan manusia biasa. Di samping bisa mencakup 
pertentangan-pertentangan yang bersifat spektakuler dari proses-proses natural, karamah juga bisa berbentuk presensi dan pengakuan tak kentara yang mungkin tidak bisa masuk dalam kesadaran orang-orang yang tidak percaya. (Ernst, 2003: 86)

Dari pendasaran di atas, keyakinan atas apa yang terjadi pada karamah wali seperti misalnya pada Manaqib Syaikh Abdul Qadir Al-Jailani atau pada cerita-cerita Sunan Gunung Djati serta wali-wali masyhur lain, memang bukanlah sesuatu yang aspek teoritiknya bisa tersentuh pendekatan positivisme. Di Barat sendiri, orang-orang seperti Immanuel Kant, sangat menyadari tentang batas-batas pengatahuan ilmiah teoritik yang dikatakannya hanya mampu menjangkau hal fenomena, tidak pada aspek noumena. Kant, melalui kritik der Reinent Vernunft telah meletakkan filsafat dan metafisika yang bersifat sintetik apriori di luar pengetahuan ilmiah teoritik, lalu ia dudukkan pada wilayah rasio praktis. Pengetahuan ilmiah menurutnya, terbatas pada wilayah fenomenal (spatiotemporal) yang terjangkau indrawi. Sedangkan wilayah filsafat (kesadaran, nilai-nilai, moral dan religi) adalah wilayah nomenal atau rasio praktis. Kant, telah meletakkan dasar bagi persoalan metodologi yang sangat kontraversial yang muncul sesudahnya (terutama pertentangan antara Naturwisenschaften dengan

Geistesswissenschaften atau antara Erkleren dengan Verstehen (Lubis, 2003:59).

Husserl yang berkesimpulan bahwa sumber krisis masyarakat Barat, karena hegemoni saintisme dalam segala lapangan kehidupan. Tidak berlebihan Husserl berpendapat, kalau kata kunci dari krisis ini adalah perkembangan ilmu pengetahuan alam. (Brower, 1986:18) Sumber dari istilah fenomenologi telah mulai dipergunakan pada abad kedelepan belas dalam tulisan-tulisan Johan Heinrich Lambert, seorang pengikut Cristian Woff yang mempergunakan kata tersebut dalam bukunya Novus Organon. Dia bertujuan menegaskan suatu ilmu penampakan yang membantu kita beranjak dari penampakan kepada kebenaran (Moran, 2001:6-7) Edmund Husserllah orang yang pertama kali membicarakan secara formal penggunaan istilah tersebut dalam bukunya Logical Investigations.

Positivisme telah menjadi kekuatan hegemonik masyarakat Barat. Semua perkembangan ilmu mesti tunduk di bawah kendali yang sama untuk melihat kenyataan semata-mata dari gejala fisik. Dehumanisasi merupakan sesuatu yang tidak dapat dihindarkan. Manusia, tidak dipahami secara utuh, dengan segala cakupan dimensinya karena semua mesti dapat diverifikasi berdasar pendekatan metode ilmiah. Maka Husserl tampil untuk memberikan refleksi kritis terhadap ilmu pengetahuan modern yang, tercakup dalam tiga langkah. Pertama, bahwa ilmu pengetahuan jatuh pada objektivisme yakni memandang dunia sebagai susunan fakta-fakta objektif dan diekspresikan secara objektif Kedua, kesadaran manusia ditelan oleh tafsiran objektivitas, karena itu ilmu pengetahuan tidak membersihkan diri dari kepentingan dunia sehari-hari. Ketiga, teori yang dihasilkan dari usaha membersihkan pengetahuan dari kepentingan adalah teori sejati. Pada dasamya, krisis ilmu pengetahuan dapat dikatakan dimulai dari kesalahpahaman disiplin-disiplin ilmiah terhadap teori sejati tersebut. (Lubis, 2003 : 72)

Husserl menolak kecenderungan naturalisme yang telah mempergunakan rumusan-rumusan matematis sebagai metode tunggal untuk menjelaskan berbagai fenomena alam serta aliran positivisme menganggap bahwa hasilnya sebagai fakta pada dirinya sendiri. Tidak hanya menyangkut keberadaan alam semesta, pemutlakan atas metode ilmiah, bahkan telah mereduksi nilai-nilai manusia serta menganggapnya semata sebagai faktafakta alamiah yang dapat dijelaskan dengan pendekatan objektif. Padahal manusia, dengan segala kompleksitas misterinya, adalah pemberi makna atas fakta-fakta tersebut. Dari titik ini dapat kita pahami bahwa fenomenologi yang dipopulerkan Husserl, mesti ditempatkan dalam konteks perlawanan terhadap dominasi cara pandang saintisme-positivisme. Pandangan-pandangan fenomenologisnya, tidak lain adalah satu altematif metode untuk 
menentang dominasi serta hegemoni positivisme yang telah merasuki berbagai dimensi kehidupan manusia modern.

Fenomenologi, berkebalikan dengan kecenderungan positivisme yang membuat kalkulasi manusia hanya berdasar pada ukuran fisik semata. Sebagai sebuah bentu refleksi langsung, dia berusaha untuk "memanusiakan" manusia serta kembali kepada fenomen sebagai dunia yang dihayati (labenswelt) baik sebagai realitas di luar kesadaran maupun realitas yang berhubungan dengan kesadaran. Di sini, fenomena bukan lagi menampakkan objekobjek, tetapi penampakan di depan kesadaran. Untuk mencapai hakikat sesuatu (wesenchau), dibutuhkan tindakan reduksi melalui tiga langkah:

Pertama, reduksi fenomenologis (epokhe); maksudnya adalah menaruh dalam tanda kurung sifat realitas dunia. Misalnya teori-teori tentang manusia, sekarang tinggalkanlah teoriteori itu, lalu lihatlah manusia sebagaimana yang dia alami. Itulah yang harus dianalisa untuk mencari hakikatnya. Yang tidak termasuk hakikat kurung saja sehingga yang tertingal hanyalah fenomen yang menunjukkan evidensi absolut, sedangkan dari sudut subjek yang tinggal adalah kesadaran mural.

Kedua, reduksi eiditis (idoes); untuk memperoleh yang hakiki dalam suatu fenomena, haruslah menangkap objek itu sendiri (ding selbst) dan bukan barang luar (aussere gegenstand). Terkait kontak dengan dunia luar, bararti langsung mengamati (das ding an sich). Menangkap berarti merekonstruksi objek.

Ketiga, reduksi transendental; sebagai cara untuk menemukan sumber terakhir dari sruktur pengenalan. Melalui reduksi ini, kita "mengurung" semua yang berhubungan dengan "aku" yang tidak jelas, aku yang empiris (Misalnya aku dalam keadaan duduk, aku yang sedih). Sekarang yang tinggal adalah kesadaran yang idak empiris lagi "aku di atas semua pengalaman". Jadi, yang kita mengerti yang ada di pengalaman. (Lubis, 2003:74-75)

Dengan cara mereduksi benda-benda pada presupossition yang menentukan, maka filsafat kemudian bisa membangun dasar-dasar ilmu rigorus. Dalam mengembangkan landasan rasional filsafat, Husserl menegaskan untuk kembali pada hakikat benda-benda itu sendiri (back to the thing themselves) yang berrnakna membebaskan pemahaman dari subjektivitas dari asumsi-asumsi dan teori-teori. (Lubis, 2003:75) Untuk mencapai dasar-dasar termaksud, seseorang mesti menempuh suatu proses metode dalam posisi yang transenden, suatu posisi yang memungkinkan kita bisa memaknai benda-benda, sebagaimana adanya serta terlepas dan segala bentuk prasangka.

Adalah Dr. Ajid Tohir telah menulis disertasi tentang Syaikh Abdul Qadir Al-Jailani dengan judul Historisitas dan Signifikansi Kitab Manaqib Syaikh Abdul Qadir Al-Jailani Dalam Historiografi Islam. (Tohir, 2011) Disertasi ini mempergunakan pendekatan fenomenologi sebagai perangkat metodologinya untuk mengurai peristiwaperistiwa yang ada dalam teks-teks Manaqib untuk menggambarkan hageografi sufi sebagai fakta mental yang benar-benar terjadi. Dasar yang dijadikanya sebagai fundamen analisis fenomenologis tersebut adalah kutipannya terhadap pandangan Edmund Husserl dalam karyanya The Crisis of European Science and Transcendental Phenomenology, mengungkapkan bahwa konsep "dunia kehidupan" (labenwelt) merupakan konsep yang bisa menjadi dasar untuk mengatasi ilmu pengetahuan yang tengah mengalami krisis akibat pola pikir positivistik dan saintistik, yang pada prinsipnya memandang semesta sebagai sesuatu yang teratur mekanis seperti halnya kerja mekanis jam. Akibatnya, adalah terjadinya 'matematisasi alam' di mana alam dipahami sebagai satu keteraturan (angkaangka). Pendekatan ini telah mendehumanisasi pengalaman manusia karena para saintis telah menerjemahkan pengalaman manusia ke formula-formula impersonal. (Tohir, 2013:134)

Pendekatan saintisme di atas, telah menempatkan manusia pada batas-batas obyek fisik bologisnya semata sembari mereduksi dimensi pengalaman spiritual yang tidak bisa dipisahkan dari dunia kehidupan itu sendiri. Lewat cara pendang fenomenologi, sejumlah 
pengalaman ruhani yang ada dalam Manaqib Syaikh Abdul Qadir Al-Jailani seperti yang ada dalam Tafrihul Khatir fii Manaaqibi Sayyid Abdul Qadir serta ditulis Syaikh Muhyiddin Irbili (Irbili, 1328 H.) baik sebagai hagiografi maupun sebagai historiografi sufi, bisa diterima secara apa adanya. Hagiografi ini, dari mulai pundak Syaikh yang dipijak saat Rasulullah akan naik ke pungung buraq pada peristiwa Isra Mikraj, pendidikan ruhiah oleh Nabi Khidir di tegalan Irak, kemampuannya mengenggam kehidupan jin dan setan beserta ke karamahkaramah yang lain, bukanlah hal fiktif semata. Tapi benar-benar terjadi sebegai sebuah pengalaman ruhani.

Pengalaman-pengalaman ruhani Syaikh Abdul Qodir Al-Jailani serta wali-wali lain termasuk Sunan Gunung Djati memang bisa ditolak dengan kadar kemampuan rasionalitas manusia yang sangat terbatas. Kaum rasionalis serta empirisis, dalam pengertiannya yang sangat ekstrim akan menolak hagiografihagiografi yang menarasikan hal-hal khawariq para wali. Hal inilah yang akan membuat peristiwa mikraj ruhani Sunan Gunung Djati hanya dipandang sebagai sarana legitimasi dengan cara melakukan "peniruan" terhadap Isra Mikraj Nabi. Peristiwa pertemuan Sunan Gunung Djati dengan Rasulullahpun, ditolak kemungkinannya. Padahal dalam hagiografi sufi seperti ditulis oleh Martin Van Bruinessen, komunikasi spiritual dalam wujud pertemuan ruhaniah yang disebut barzakhi atau uwaisi, walaupun ditolak oleh sebagian kecil sufi, tetapi sebagain besar mereka mengakui kemungkinan ini. (Van Bruinessen, 1996: 49)

Martin Van Bruinessen memberikan contoh pendiri tarekat Tijaniah, Syaikh Ahmad AlTijani telah dipercayai berjumpa ruh Nabi sendiri dan menerima pelajaran dari beliau. Contoh tarekat lain adalah Sanusiyah. Di Indonesia, tarekat ini bernama Idrisiah serta berpusat di Pagendingan Tasikmalaya. Pendiri dari tarekat ini adalah Muhammad Ibnu Ali AlSanusi, adalah murid dari Ahmad Ibnu Idris Al-Fasi, dan di atasnya hanya kita dapati tiga generasi guru: 'Abd Al-Wahhab Al-Tazi, Ahmad Ibnu Mubarak Al-Lamti, dan 'Abd AlAziz Al-Dabbagh. 'Abd Al-Aziz dipercayai telah menerima pelajaran dari Nabi Khidir serta pada gilirannya dibaiat Nabi Muhammad untuk mengajarkan tarekat yang di kemudian hari terkenal dengan nama tarekat Sanusiyah ini. (Van Bruinessen, 1996: 49)

Peristiwa-peristiwa ruhani yang dialami Sunan Gunung Djati serta Syaikh Ahmad Tijani yang mendapat pelajaran dari Rasulullah serta Syaikh 'Abd Al-Aziz Al-Dabbagh yang mendapat pelajaran dari Nabi Khidir serta juga dibaiat Nabi, memiliki nilai kebenaran tersendiri. Secara fenomeologis ia berasal dari 'endapan makna' yang rekonstruksinya didapat lewat intensionalitas (kesadaran) individu serta bentuk karamah seperti ini dihayati sebagai sebuah kebenaran ketersingkapan rahasia batin kaum sufi.

\section{MIKRAJ RUHANI SUNAN GUNUNG DJATI}

Kelahiran Sunan Gunung Djati merupakan hasil perpaduan dua budaya yang berbeda. Dari sisi ayah, ia keturuanan raja Mesir, sementara dari sisi ibu, ia merupakan keturunan raja Pajajaran. Dalam Carita Purwaka Caruban Nagari terdapat penjelasan tentang silsilah Sunan Gunung Djati dari sisi ayah yang dimulai dari Nabi Muhammad Saw, lalu Ali bin Abi Thalib yang beristrikan Fatimah binti Muhammad, dan selanjutnya Sayid Husain, anak kedua Fatimah dengan Ali. Husain mempunyai anak yang bernama Zainal Abidin, dan Zainal Abidin mempunyai anak yang bernama Muhammad Baqir. Muhammad Baqir kemudian berputrakan Ja'far ah-Shadiq dari Parsi. Ja'far ash-Shadiq punya anak bernama Kasim al-Malik, Kasim punya anak bernama Idris, Idris berputrakan Al-Baqir, Al-Baqir berputrakan Ahmad, Ahmad mempunyai putra bernama Baidillah Muhammad, Baidilillah berputrakan Alwi dari Mesir. Alwi berputrakan Abdul Malik, dan Abdul Malik berputrakan Amir dai India. Kemudian Amir mempunyai anak bernama Jamaludin dari Kamboja. Jamaludin mempunyai putra bernama Ali Nur Alim yang menikah dengan putri Mesir. Dari perkawinan mereka, lahirlah Syarif Abdullah yang kemudian menikah dengan Syarifah 
Mudaim atau Nyai Rara Santang, dan kemudian berputrakan Syarif Hidayat atau Syarif Hidayatullah (Suryaman, 2015: 28-29). Berdasarkan silsilah di atas, Sunan Gunung Djati merupakan generasi ke-18 dari Nabi Muhammad Saw.

Melalui garis ibu, diterangkan bahwa Sunan Gunung Djati adalah keturunan raja Galuh Pajajaran, yang berawal dari Maharaja Galuh pertama, yaitu Pakuwan Maharaja Adi Putra yang mempunyai anak bernama Prabu Ciung Wanara, Ciung Wanara mempunyai anak bernama Sri Ratu Purbasari, dan Purbasari punya anak bernama Prabu Lingga Hiyang. Lingga Hiyang punya anak bernama Prabu Lingga Wesi, Lingga Wesi punya anak bernama Prabu Wastu Kencana, Wastu Kencana berputrakan Prabu Susuk Tunggal, Susuk Tunggal mempunyai putra bernama Prabu Banyak Larang, Banyak Larang mempunyai putra bernama Prabu Mundingkawati, Mundingkawati punya putra bernama Prabu Angga Larang, dan Prabu Angga Larang berputrakan Prabu Siliwangi (Suryaman, 2015: 29)

Prabu Siliwangi menikah dengan Nyai Subang Larang, putri Patih Singapura, yaitu Ki Gede Tapa, dari istrinya yang bernama Nyai Ratna Kranjang. Ratna Kranjang sendiri adalah putri Ki Gede Kasmaya yang menjadi penguasa Cirebon Girang, salah satu dukuh di dalam wilayah Wanagiri. Pada usia 14 tahun, Nyai Subang Larang dibawa oleh bibinya, Nyai Lara Huda (istri Ki Dampu Awang), ke Malaka dan menetap di sana selama dua tahun, kemudian kembali ke Jawa dan selanjutnya berguru kepada Syaikh Qura di Pondok Qura Karawang. Pada kira-kira tahun 1422, Nyai Subang Larang menikah dengan Prabu Siliwangi. Dari pernikahan mereka, lahirlah tiga orang anak, yaitu dua putra dan satu putri; yang putri adalah Nyai Rara Santang yang kemudian menikah dengan Raja Mesir dan melahirkan Syarif Hidayat dan adiknya, Syarif Nurullah. (Suryaman, 2015: 29)

Syaikh Syarif Hidayatullah yang terkenal dengan sebutan Sunan Gunung Djati, lahir bertepatan pada tanggal sebagaimana Rasul dilahirkan. Saat permaisuri Raja Abdullah, sudah cukup bulan untuk bersalin. Adapun antara hari bulan Maulud tanggal 12 bakda shubuh, Syarifah Mudaim melahirkan seorang jabang bayi yang elok sekali, cahayanya meredupkan cahaya matahari. Sultan bergembira sekali, lalu dibawa thawaf di Baitullah, dirubung oleh para ulama dan para mukmin, diberi nama Syarif Hidayatullah, bertepatan pada tahun $1448 \mathrm{M}$. Antara 60 hari kemudian rombongan Jeng Sultan, permaisuri, dan putra berlayar pulang kembali datang di negara Mesir.

Disamping hari kelahiran yang sama dengan Rasulullah, kisah lain yang mirip dengan riwayat Nabi Muhammad adalah kisah "Mikraj" Sunan Gunung Djati yang ditampilkan dalam Wawacan Sunda pupuh ketigabelas dan empat belas, Babad CerbonHadi pupuh keempatbelas dan kelimabelas, Babad Cerbon-Brandes pupuh kesepuluh dan ke sebelas, dan Carub Kanda pupuh keempatbelas dan kelimabelas. Adapun ringkasan ceritanya seperti dalam kutipan Dadan Wildan adalah sebagai berikut:

Suatu ketika Syarif Hidayatullah bertemu dengan seorang wanita jelmaan Nabi Ilyas bernama Nyai Atma yang memberinya kue dan roti yang berkhasiat dapat berbicara berbagai macam bahasa, seperti Arab, Kures, Inggris, dan Turki. Nyai Atma menyarankan agar menangkap sesorang yang mengendarai kuda sembrani di angkasa. Seketika itu, di angkasa terlihat seseorang menunggang kuda yang tidak lain adalah Nabi Khidir. Syarif Hidayatullah segera mengejarnya dan dapat menangkap ekornya, namun dibantingkan oleh Nabi Khidir sehingga ia terjatuh di negeri Ajrak.

Dihadapan raja negeri Ajrak bernama Abdullah Safar ia menceritakan maksudnya untuk mencari Nabi Muhammad. Oleh Abdullah Safar, ia diberi buah Kalmuksan. Saking nikmatnya memakan buah, membuat Syarif Hidayat terbius dan tidak sadarkan diri. Abdul Safar kemudian memanggil Patih Sadat Satir dan Osalasil untuk memasukkan Syarif Hidayat ke dalam masjid Sungsang. Dari masjid Sungsang, Syarif Hidayat "mikraj" ke langit dan menemui ruh orang-orang yang mati 
sabil, serta mukmin yang alim dan kuat beribadat, dari langit pertama hingga langit ke tujuh.

Di langit kedua ia bertemu dengan ruh-ruh wanita yang setia dan patuh pada suami, di langit ketiga ia bertemu dengan Nabi Isa yang memberinya nama Syaikh Syarif Iman Tunggal, di langit keempat ia bertemu dengan ribuan malaikat yang dipimpin oleh Jibrail, Mikail, Israfil, dan Ijrail. Malaikat Jibril memberi nama Syaikh Kembar, Mikail memberi nama Syaikh Surya, Isrofil memberi nama Syaikh Jabar, dan Ijrofil memberi nama Syaikh Brahan. Di langit kelima ia bertemu dengan para nabi yang memberinya nama, Nabi Adam memberi nama Syaikh Syarif Raja Wali, Nabi Ibrahim memberi nama Syarifullah, dan Nabi Musa memberi nama Syaikh Ma'ruf. Syarif Hidayat selanjutnya melihat neraka dinding jalal, dan meniti sirotol mustakim. Akhirnya ia tiba di langit ke tujuh dan melihat cahaya terang benderang. Di langit ketujuh, Syarif Hidayat bertemu dengan ruh Nabi Muhammad yang mengajarkan inti ajaran agama Islam, wejangan-wejangan, serta memberi jubah (pakaian) Rasulullah yang mempunyai sifat menyatu dengan Muhammad (sipat tunggal lan Muhammad). Setelah mendapat wejangan dari ruh Nabi Muhammad, Syarif Hidayatullah turun kembali ke bumi dan tiba di Gunung Jati. (Wildan, 2012: 174-177)

Penulis buku menganggap bahwa cerita di atas mengandung unsur peniruan dan pembawa ajaran agama dari cerita Nabi Muhammad. Unsur peniruan dan kenabian dimaksudkan agar tokoh Sunan Gunung Djati dianggap sebagai orang yang mempunyai otoritas keilmuan dalam agama Islam. Sebagai penyebar agama Islam Sunan Gunung Djati ditampikan sebagai sosok yang riwayat kehidupannya ditiru dari cerita Nabi Muhammad bahkan pernah "bertemu" dengan Nabi Muhammad. Bahkan lebih jauh penulis buku menganggap bahwa cerita ini mengandung legitimasi Sunan Gunung Djati sebagai penyebar agama Islam, karena ia "ditugasi" oleh Nabi Muhammad sebagai pembawa ajaran Islam untuk menyebarkan agama tersebut dimana ia berada, tidak hanya di tanah Jawa tetapi juga sampai ke negeri Cina. (Wildan, 2012: 177)

Apakah cerita tersebut hanya mengandung unsur peniruan semata demi legitimasi Sunan Gunung Djati sebagai penyebar agama Islam? Pertanyaan tersebut bisa dijawab dengan pasti bahwa peristiwa mikraj ruhani bukan semata unsur peniruan atau rekaan pengarang. Pasti tidak masuk akal kalau ukurannya semata rasionalitas. Fokus ilmuwan Barat pada ilmu alam, dalam tulisan Kholid Al-Walid (TT:53) mereka melupakan intuisi sebagai salah satu sumber pengetahuan. Adalah Henri Bergson (1859-1941), seorang filosof Perancis yang mengemukakan bahwa manusia dengan akalnya dapat mengetahui zahir sesuatu, namun untuk mengetahui hakikat sesuatu diperlukan eleman lain yang mengantarkan dirinya pada mukasyafah atau penyaksian hakikat. Jiwa manusia bagaikan cermin yang padanya tergambarkan beragam objek yang bersifat ruhaniah yang tidak mungkin diperoleh melalui indra dan akal, Namun demikian halnya seperti Indra dan Akal membutuhkan kesehatan dan ketajaman, sehingga kesimpulan yang didapat menghasilkan keyakinan demikian demikian juga dengan jiwa hendaklah berada dalam kesucian, kejernihan dan kemualiannya, sehingga dapat menangkap objek-objek ghaib tersebut dengan jelas. (AlWalid, TT: 54)

Kalau seseorang menyangkal apa yang terjadi pada Sunan Gunung Djati terkait pertemuannya dengan Nabi serta nabi-nabi yang lain, bagaimana pula dengan apa yang ditulis Muhyiddin Irbili di dalam Tafrihul Khatir fii Manaaqibi Sayyid Abdul Qadir (Irbili, 1328 H:4) bahwa Rasulullah Saw juga pada malam mikraj melihat ruh para Nabi di langit dan sholat bersama mereka di Baitul Maqdis. Padahal dari sisi linearitas waktu, masa kehidupan Nabi Saw dengan nabi-nabi lain, terentang jarak ratusan sampai ribuan tahun. Lebih jauh Syaikh Muhyiddin Irbili menulis seperti dalam kutipan Ajid Tohir bahwa emanasi ruh sempurna (ruh orang-orang yang telah disempunakan) terwujud ke dalam tiga bentuk, pertama, memberikan pengajaran di alam lahir melalui perkataan dan berhadapan 
(tatap muka) biasa dalam pengajaran umum. Kedua, tidak melalui penampakan fisik, akan tetapi proses pengajaran itu sendiri tetap berjalan antara si pendidik dengan yang dididik seperti halnya pengajaran Nabi Muhammad Saw terhadap Uwais Al-Qarni yang juga hidup sezaman, tapi dengan Nabi tidak pernah bertemu secara fisik. Bentuk pendidikan ruhani yang juga tidak terjadi melalui pertemuan jasad fisik adalah antara Imam Jakfar Shadiq terhadap Abu Yazid yang berjauhan kurun waktu kehidupannya, namun antara keduanya terjadi proses penyampaian pengetahuan. Begitu juga pendidikan nabi Muhammad kepada umatnya setelah beliau tiada. Ketiga, bentuk pendidikan melalui mimpi, sebagaimana biasa dilakukan oleh ruh-ruh suci terhadap mereka-mereka yang dikehendaki Allah Swt. (Tohir, 2013:137)

Dengan demikian, seperti dalam kutipan Ajid Tohir, para ulama tasawuf menyebut dua model komunikasi ruhani yakni jenis kedua dan ketiga disebut pendidikan ruhani melalui emanasi barakah (faidl al-barakah). Pendidikan ruh yang masih di alam kesendiriannya, contohnya seperti ruh Nabi Muhammad Saw memberikan pengajaran kepada ruh para nabi. Pengajaran demikian dinamakan dengan tarbiyaturruh.(Tohir, 2013: 138). Apa yang terjadi pada Sunan Gunung Djati terkait dengan perjumpaannya dengan Rasulullah Saw, tidak lain adalah bentuk faidl al-barakah serta bagian dari tarbiyaturruh yang dituliskan P.S. Sulendraningrat ramaguru Tarekat Satariyah di Perguruan Caruban Krapyak Keprabonan di dalam Babad Tanah Sunda Tanah Cirebon sebagai berikut:

Jeng Maulana terharu, nikmat, tiada lain yang terlihat hanya cahaya yang lebih agung laksana meliputi tujuh dunia. Jeng Maulana lalu sujud, seribu nikmat, seribu rahmat laksana hilangnya papan dengan tulis. Maka lalu ada suara yang terdengar, janganlah anda sujud kepada sesuatu yang baharu, sujudlah kepada yang Qadam. Jeng Maulana mendengar suara itu, lalu mengangkat kepalanya ke atas, melihat kepada haki yang sesunguhnya. Jeng Nabi Muhammad memberi wejangan sejatinya sahadat yang bangsa lathifatusirri. Setelah usai olehnya mejang, Jeng Nabi berkata,"Aku beri anda gelar Insan Kamil, menjabat sebagai Wali Kutub, tidak adanya aku ya adanya anda, bahkan tidak ada wujud dua dan anda gelarkanlah agama Islam, rukunya lima perkara, sahadat, salat, zakat, naik haji bagi orang yang kuasa di jalannya dan patuhilah apa yang tersebut dalam Al-Qur'an, dan ingat anda janganlah mengunggul-ungguli menghebathebati yang tanpa amal kebajikan dan anda bergurulah apa adat biasa di dunia, yang benar lakukanya nastiti hati-hati yang sejatinya. (Sulendraningrat, 1984: 27)

Dalam perspektif tasawuf, perjumpaan ruhani antara Sunan Gunung Djati dengan Rasulullah Saw bisa terjadi ketika seseorang sudah bisa terlepas dari orientasi alam materi, dan maqamnya terus naik menjangkau alam ruhiah yang suci. Dalam pandangan filsuf terbesar Islam madzhab Hikmah Muta'aliyah Mulla Sadra, kemungkinan tersebut bisa terjadi karen ruh manusia jika terlepas dari raga akan melakukan perjalanan kepada Tuhannya untuk menyaksikan beragam tanda-tanda kebesaran. Pensuciannya dari segala kemaksiatan, syahwat dan keterikatan akan menyampaikannya pada cahaya makrifat dan keimanan kepada Allah Taala serta alam malakut yang tinggi (Al Walid, TT:56). Cahaya yang demikian, dalam visi Mulla Sadra, jika terepleksikan dan tersubtansikan dalam istilah yang digunakan para filosof dengan istilah filsafat, disebut dengan akal aktif dan dalam syariat kenabian disebut dengan $A l-R u h A l$ Qudsi.

\section{SIMPULAN}

Pendekatan positivisme terhadap realitas, memiliki watak reduksionistik serta parsial, hanya melihat masalah dari dimensi fisik semata. Masalah mukjizat para nabi serta karamah para wali tidak akan terjangkau dengan pendekatan ini. Dengan cara pandang saintisme serta positivisme, khawariqul 'adah para wali adalah sesuatu yang tertolak. Namun, pendekatan fenomenologi yang mendekati realitas sebagai mana adanya "back to the thing themselves" bisa menjangkau kenyataan 
tersebut sebagai sebuah fakta mental, dan bisa dipahami secara tepat pada posisi sebagai pengalaman ruhaniah.

Pengembaraan ruhaniah Sunan Gunung Djati yang menerima faidl al-barakah serta tarbiyaturruh lewat perjumpaannya dengan Rasulullah, bukanlah fiksi serta rekaan pengarang semata. Tetapi kemungkinan itu memang bisa terjadi karena terkait maqamat ruhaninya yang sangat tinggi sebagai quthb auliya pada masanya. Pengalaman ruhani Sunan Gunung Djati tersebut adalah bagian integral dari pendakian spiritual para wali sufi yang lain seperti Syaikh Abdul Qodir AlJailani, 'Abd Al-Aziz Al-Dabbagh serta Syaikh Ahmad Tijani. Kemungkinan itu juga tidak tertolak secera filosofis dalam tradisi filsafat Islam seperti lewat pandangan Mulla Sadra, filosof dari tanah tinggi Parsi.

Jikalah teori Barat yang diambil, untuk memahami hal-hal yang bersifat pendidikan ruhiah tersebut, mesti dicari teori Barat yang relevan sebagai pisau analisis terhadap salah satu dimensi esoterisme Islam. Jikalah hal ini tidak dilakukan, kajian tentang kehidupan wali dengan karamah-karamah yang ada pada mereka, niscaya terjebak pada kedangkalan cara pandang kaum positivis semata.[]

\section{E. DAFTAR PUSTAKA}

Al-Walid, Kholid, Epistemologi Islam, Jakarta STFI Sadra, TT.

Dadan Wildan, Sunan Gunung Djati, Petuah, Pengaruh, Dan Jejak-Jejak Sang Wali Di Tanah Jawa, Jakarta, Salima, 2012.

Ernst, Carl W, Ajaran Dan Amaliah Tasawuf, Jogjakarta, Pustaka Sufi, 2003

Irbili, Muhyiddin, Tafrihul Khatir fii Manaaqibi Sayyid Abdul Qadir, Mustafa Bab Al-Halabi, $1328 \mathrm{H}$.

Lubis, Akhyar Yusup, Paul Feyerabend, Penggagas Anti Metode, Mizan, Bandung, 2003.

Positivisme, Positivisme Logis, Siklus

Empiris, Program Pasca Sarjana (S2/S3)
Universitas Indonesia, Depok, 2002/2003.

Moran, Dermot, Introduction to Phenomenology, Routledge, London \& New York, 2001.

Suryaman, Eman, Jalan Hidup Sunan Gunung Jati, Sejarah Faktual Serta Filosofi Kepemimpinan Seorang Pandhita Raja, Bandung, Nuansa Cendikia, 2015

Sulendraningrat, P.S., Babad Tanah Sunda Babad Cirebon, Cirebon, 1984.

Tohir, Ajid Historisitas dan Signifikansi Kitab Manaqib Syaikh Abdul Qadir Al-Jailani Dalam Historiografi Islam, Jakarta, Badan Diklat serta Litbang Kementerian Agama, 2011

"Historiografi Sufi Dalam Perspektif Fenomenologi", Jurnal Al-Tsaqafa, JanuariJuni 2013.

Van Bruinessen, Martin, Kitab Kuning, Pesantren dan Tarekat, Bandung, Mizan, 1999 